\title{
Amino acid limitation regulates gene expression
}

\author{
Alain Bruhat $\dagger$, Céline Jousse $\dagger$ and Pierre Fafournoux* \\ Unité de Nutrition Cellulaire et Moléculaire, INRA de Theix, 63122 Saint Genès Champanelle, France
}

\begin{abstract}
In mammals, the plasma concentration of amino acids is affected by nutritional or pathological conditions. For example, an alteration in the amino acid profile has been reported when there is a deficiency of any one or more of the essential amino acids, a dietary imbalance of amino acids, or an insufficient intake of protein. We examined the role of amino acid limitation in regulating mammalian gene expression. Depletion of arginine, cystine and all essential amino acids leads to induction of insulin-like growth factor-binding protein-1 (IGFBP-1) mRNA and protein expression in a dose-dependent manner. Moreover, exposure of HepG2 cells to amino acids at a concentration reproducing the amino acid concentration found in portal blood of rats fed on a lowprotein diet leads to a significantly higher $(P<0.0002)$ expression of IGFBP-1. Using CCAAT/enhancer-binding protein homologous protein $(C H O P)$ induction by leucine deprivation as a model, we have characterized the molecular mechanisms involved in the regulation of gene expression by amino acids. We have shown that leucine limitation leads to induction of $C H O P$ mRNA and protein. Elevated mRNA levels result from both an increase in the rate of $C H O P$ transcription and an increase in mRNA stability. We have characterized two elements of the CHOP gene that are essential to the transcriptional activation produced by an amino acid limitation. These findings demonstrate that an amino acid limitation, as occurs during dietary protein deficiency, can induce gene expression. Thus, amino acids by themselves can play, in concert with hormones, an important role in the control of gene expression.
\end{abstract}

\section{Résumé}

Chez les mammifères, la concentration plasmatique d'acides aminés peut varier selon les conditions nutritionnelles ou pathologiques. Par exemple, une déficience en un (ou plusieurs) acide(s) aminé(s) essentiel(s), un régime déséquilibré ou une restriction protéique vont entraîner une altération du profil plasmatique en acides aminés. Une sous-nutrition protéique a également pour conséquence un arrêt de la croissance dû en partie à une baisse de la concentration d'IGF-1 et à une très forte augmentation d'IGFBP-1 plasmatique. Nous avons montré qu'une déplétion en acides aminés essentiels ainsi qu'en arginine et cystine entraîne une forte induction de l'expression d'IGFBP-1 par des hepatocytes isolés ainsi que par des cellules d'hépatome de foie (HepG2) en culture. De plus, le traitement de cellules HepG2 par des concentrations d'acides aminés reproduisant celles trouvées dans le sang afférent au foie de rats nourris avec un régime pauvre en protéine conduit à une induction significative d'IGFBP-1. En utilisant comme modèle l'induction du gène $C H O P$ par une carence en leucine nous avons caractérisé les mécanismes moléculaires impliqués dans la régulation de l'expression des gènes par les acides aminés. Nous avons montré que l'élévation du messager de $C H O P$ en réponse à une carence en leucine est due à une augmentation de la transcription ainsi qu'à une stabilisation du messager. Nous avons également caractérisé deux éléments du gène $C H O P$ essentiels à l'activation de la transcription consécutive à une limitation en acide aminé. Ces résultats montrent qu'une limitation en acides aminés similaire à celle observée lors d'un régime pauvre en protéine peut induire l'expression de gènes cibles. Les acides aminés peuvent donc par eux mêmes et de concert avec les hormones, jouer un rôle important dans le contrôle de l'expression des gènes.

Gene expression: Amino acids: Insulin-like growth factor-binding protein-1

\footnotetext{
Abbreviations: CAT, chloramphenicol acyltransferase; C/EBP, CCAAT/enhancer-binding protein; $C H O P$, C/EBP homologous protein; IGF, insulin-like growth factor; IGFBP-1, IGF-binding protein-1; LUC, luciferase; $\mathrm{p} C H O P, C H O P$ promotor.

*Corresponding author: Dr Pierre Fafournoux, fax +3347362 45 70, email fpierre@ clermont.inra.fr

$\nmid$ Contributed equally to the work presented in this paper.
} 
All cells regulate gene expression in response to changes in the external environment. Metabolite control of gene expression has been well documented in prokaryotes and lower eukaryotes. Specific mechanisms have evolved to allow these organisms to metabolize quickly various molecules based on their availability in the external medium. However, much less is known about the response of multicellular organisms to nutrient variations. The control of gene expression differs in many aspects from that operating in single-cell organisms, and involves complex interactions of hormonal and neuronal factors. Although not as widely appreciated, nutritional and metabolic signals play an important role in controlling gene expression in multicellular organisms. It has been shown that major (carbohydrates, fatty acids, and sterols) or minor (minerals and vitamins) dietary constituents participate in the regulation of gene expression in response to nutritional changes (for reviews, see Girard et al. 1994; Gurney et al. 1994; Vaulont \& Kahn, 1994; Towle, 1995). There is considerably less information available concerning the control of mammalian gene expression by amino acids (Kilberg et al. 1994). However, the plasma concentration of free amino acids shows striking alterations according to the nutritional or pathological conditions. The current investigation examines the regulation of two genes, insulin-like growth factorbinding protein-1 (IGFBP-1) and CCAAT/enhancerbinding protein $(\mathrm{C} / \mathrm{EBP})$ homologous protein $(\mathrm{CHOP})$ by amino acids. More particularly, we sought to determine (1) whether a change in blood amino acid concentrations following a change in the nutritional status leads to a modification of IGFBP-1 expression level, and (2) the molecular mechanisms involved in $\mathrm{CHOP}$ regulation by a leucine limitation.

\section{Regulation of insulin-like growth factor-binding protein-1 by amino acids limitation}

An example of amino acid limitation: protein undernutrition

Protein undernutrition has its most devastating consequences during growth. Deficiency of any one or more of the essential amino acids or a deficient protein intake is characterized by negative $\mathrm{N}$ balance, weight loss and impaired growth in infants and children (kwashiorkor; Coward \& Lunn, 1981).

Growth is controlled by the complex interaction of genetic, hormonal and nutritional factors. A large part of this control is due to growth hormone and to the insulin-like growth factors (IGF)-I and -II (Baker et al. 1993; Binoux, 1995). The biological activities of the IGF are modulated by the IGFBP that specifically bind IGF-I and IGF-II (Walton et al. 1995; for review, see Lee et al. 1993). Of the six IGFBP, IGFBP-1 is the only one that displays rapid dynamic regulation in vivo, with serum levels varying 10 -fold or more in relation to meals. Plasma IGFBP-1 is increased by fasting (Busby et al. 1988; Cotterill et al. 1988), malnutrition (Straus \& Takemoto 1990; Donovan et al. 1991) and diabetes (Brismar et al. 1988; Suikkari et al. 1988). IGFBP-1 is mainly synthesized by the liver, and in vivo its expression is mainly controlled by insulin, growth hormone and glucose. Using IGFBP-1 administration in the rat (Lewitt et al. 1991) or in transgenic mice overexpressing hepatic IGFBP-1 (Rajkumar et al. 1995, 1996; Gay et al. 1997), it was shown that permanent hepatic expression of IGFBP-1 leads to growth retardation during both ante- and postnatal periods and impaired development of organs such as the brain.

Growth defects associated with protein malnutrition take place in the presence of normal or elevated serum levels of growth hormone (Vance et al. 1992). However, the circulating level of IGF-I is decreased whereas IGFBP-1 expression is strongly increased, suggesting that IGF-I and IGFBP-1 are differentially regulated and may play an important role in the nutritional regulation of growth (Straus, 1994; Kita et al. 1996). Straus et al. (1993) have reported a higher level of IGFBP-1 expression in protein-restricted animals than in starved animals. This difference cannot be explained by a variation in the plasma level of glucose, insulin or growth hormone. These authors suggested that other additional metabolic factors could be involved in IGFBP-1 gene regulation. In the present report, we investigate whether an amino acid limitation such as occurs in protein-restricted animals can regulate IGFBP-1 expression.

\section{Induction of insulin-like growth factor-binding protein-1 $m R N A$ and protein expression by amino acid limitation}

To understand the role of amino acids in IGFBP-1 expression, we have studied the effect of leucine limitation on IGFBP-1 mRNA and protein content in a human hepatoma cell line HepG2. We chose leucine because: (1) leucine is an essential amino acid that is poorly utilized by the cells during a $16 \mathrm{~h}$ incubation period (data not shown); (2) leucine, which is transported by system L (Palacin et al. 1998), is rapidly equilibrated through the cell membrane. Fig. 1 shows that IGFBP-1 mRNA and protein levels are

(A)

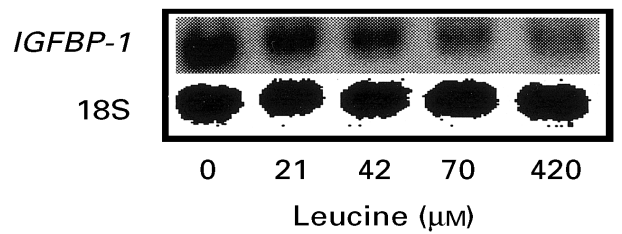

(B)

IGFBP-1

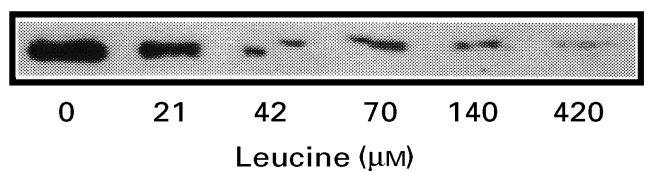

Fig. 1. Effect of leucine concentration on the expression of insulinlike growth factor-binding protein-1 (IGFBP-1) mRNA and protein in hepatoma cell line. HepG2 cells were incubated for $16 \mathrm{~h}$ in DMEM/F12 medium (Sigma, St Louis, MO, USA) containing the indicated leucine concentration. (A) Total RNA was extracted, and Northern blot analysis was performed. The blot was hybridized with a probe corresponding to human IGFBP-1. The same membrane was rehybridized with an $18 \mathrm{~S}$ probe to normalize for RNA loading. (B) A $15 \mu \mathrm{l}$ sample of culture medium was analysed for the presence of IGFBP-1 protein. Western blotting was performed using a rabbit polyclonal anti-IGFBP-1 antibody. 
very low in control cells, and increase dramatically when the leucine concentration is decreased in the culture medium. Similar results were obtained using primary culture of isolated rats hepatocytes (Jousse et al. 1998), showing that amino acid regulation of IGFBP-1 is not confined to hepatoma cells and occurs in well-differentiated isolated hepatocytes.

To characterize the role of amino acids in the control of IGFBP-1 expression we have tested the effects of individual amino acid depletion on hepatic IGFBP-1 mRNA (results not shown). Depletion of arginine, cystine and all essential amino acids has a marked effect on IGFBP-1 mRNA level in a human hepatoma cell line HepG2 (Jousse et al. 1998). It is noticeable that amino acids whose concentrations are affected by the nutritional status (Fafournoux et al. 1990) are those which play a major role in the control of IGFBP-1.

A change in nutritional status leads to a modification in blood concentration of most amino acids. However, the variation in concentration differs for individual amino acids. In order to determine whether a change in amino acid concentration corresponding to a change in nutritional status can modify IGFBP-1 expression, we reconstituted a culture medium reproducing the amino acids concentrations found in the portal blood of rats submitted to various diets (Fig. 2). Amino acid concentrations reproducing those of the portal blood of animals fed on a low-protein diet led to a significantly $(\mathrm{P}<0.0002)$ higher expression of IGFBP-1. These findings show that amino acid concentrations reproducing nutritional situations can significantly modify IGFBP-1 gene expression.

In human subjects plasma amino acids profiles have been shown to be altered in the case of malnutrition. For example, alterations have been reported when there is a deficiency of any one or more of the essential amino acids, a dietary imbalance of amino acids, or a deficient intake of protein. Moreover, malnutrition is often associated with high levels of infection and infestation. The pattern of amino acids in the plasma of malnourished subjects is also influenced by the effects of infection and loss of appetite (Jackson \& Grimble, 1990). In such a situation, the plasma concentrations of certain essential amino acids can be dramatically lowered. For example, leucine and methionine concentrations are reduced to 20 and $5 \mathrm{uM}$ respectively in the plasma of children affected by kwashiorkor (Grimble \& Waterlow, 1970; Baertl et al. 1974). Thus, in the case of

(A)

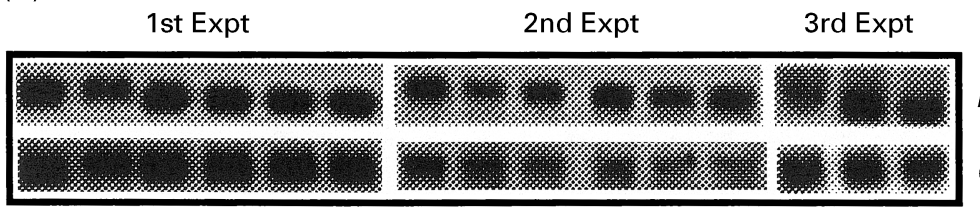

IGFBP-1

GAPDH

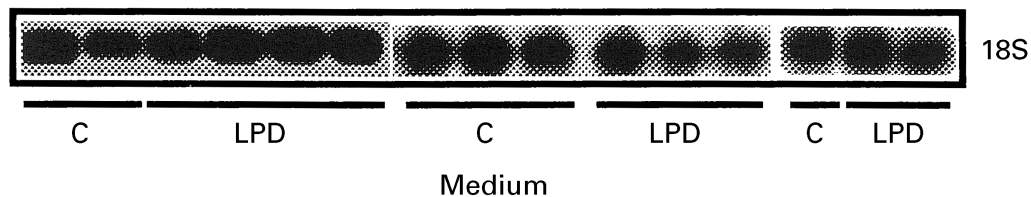

185
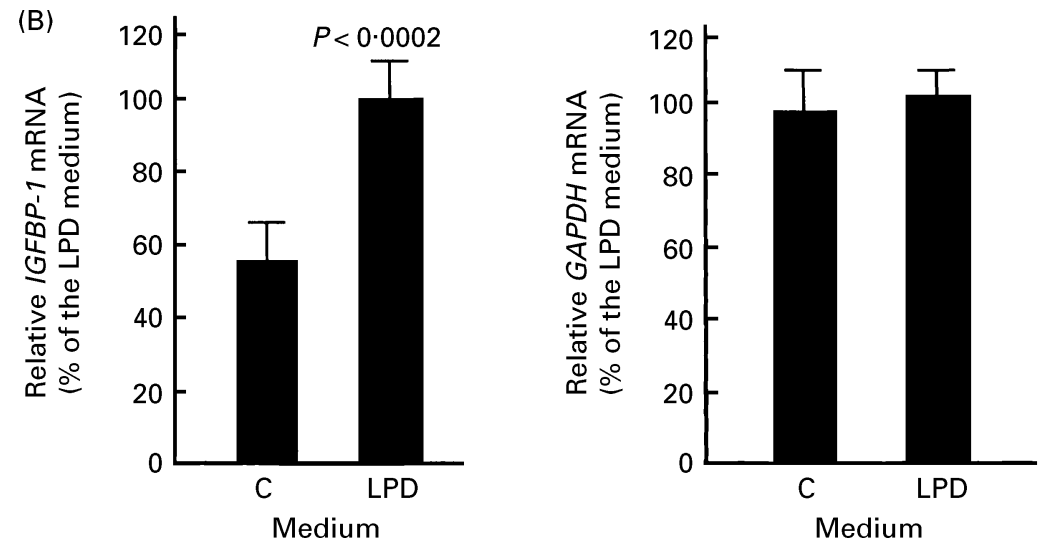

Fig. 2. Amino acid concentrations corresponding to physiological concentration modify the insulin-like growth factor-binding protein-1 (IGFBP-1) mRNA level. HepG2 cells were incubated for $16 \mathrm{~h}$ in a culture medium containing the liver afferent blood amino acid concentration corresponding to that of rats fed on a low-protein (LPD) or a standard (C) diet. Plasma afferent concentrations of amino acids are the average of data from the literature and from that of Jousse et al. (1998). Total RNA was extracted, and Northern blot analysis was performed (A). The blots were successively hybridized with a labelled probe corresponding to human IGFBP-1, glyceraldehyde-3-phosphate dehydrogenase (EC 1.2.1.12; GAPDH) and 18S. After quantification and normalization, results are given as percentages of IGFBP-1 or GAPDH expression in LPD medium (B). Values are means of three independent experiments and standard deviations represented by vertical bars. 
malnutrition amino acids by themselves play an important role in the regulation of IGFBP-1 expression, and in this fashion participate in the regulation of growth. The knowledge of the molecular basis of gene regulation by dietary protein intake is important with respect to growth regulation of young individuals living under conditions of restricted or excessive food intake.

\section{Molecular mechanisms involved in gene regulation by an amino acid limitation}

In mammalian cells, the current understanding of amino acid-dependent control of gene expression is limited. Our goal is to determine the molecular mechanisms involved in the regulation of gene expression by amino acid limitation. We focused on the regulation of one gene $(\mathrm{CHOP})$ by one amino acid (leucine). We chose leucine for the reasons mentioned previously. We chose $C H O P$ because: (1) the basal $C H O P$ expression level is very low; (2) among the amino acid-regulated genes, $C H O P$ expression exhibited the greatest induction in response to amino acid starvation; (3) CHOP is ubiquitous; (4) the $C H O P$ promoter (pCHOP) has been cloned and characterized. CHOP (also known as gadd153) is a mammalian gene whose expression is induced in all tested cells by a wide variety of stresses and agents (Bartlett et al. 1992; Luethy \& Holbrook, 1992; Carlson et al. 1993; Sylvester et al. 1994). CHOP induction is linked to the activation of an endoplasmic reticulum stress response, one that is presumably mediated by the accumulation of malfolded proteins in the endoplasmic reticulum (Wang et al. 1996). CHOP encodes a small nuclear protein related to the C/EBP family of transcription factors (Fornace et al. 1988). Members of the C/EBP family have been implicated in the regulation of processes relevant to energy metabolism, cellular proliferation, differentiation and expression of cell-type specific genes. By forming stable heterodimers with the members of the C/EBP family, CHOP protein can influence gene expression (Wang et al. 1998).

\section{The induction of $\mathrm{CHOP}$ expression by leucine deprivation involves both transcriptional and post-transcriptional mechanisms}

Recently, it was shown that leucine limitation induces CHOP expression in all cell lines tested (Bruhat et al. 1997). Leucine deprivation could increase $C H O P$ mRNA expression either by increasing the rate of transcription or by stabilizing existing transcripts, or through both mechanisms. Nuclear run-on experiments provided evidence that the rate of $C H O P$ transcription was increased by leucine deprivation (Fig. 3(A)). After $4 \mathrm{~h}$ of leucine deprivation the transcription of CHOP increased dramatically (21-fold), while the transcription of the $S 26$ ribosomal gene remained unchanged. To determine whether leucine deprivation can affect the half-life of $C H O P$ mRNA, cells were first incubated for $16 \mathrm{~h}$ in a medium lacking leucine, then incubated with actinomycin $\mathrm{D}(4 \mu \mathrm{g} / \mathrm{ml})$ in the presence or absence of $420 \mu \mathrm{M}$-leucine, and total mRNA was extracted from cells at various times. As shown in Fig. 3(B), addition of leucine resulted in a rapid decline in $C H O P$ mRNA
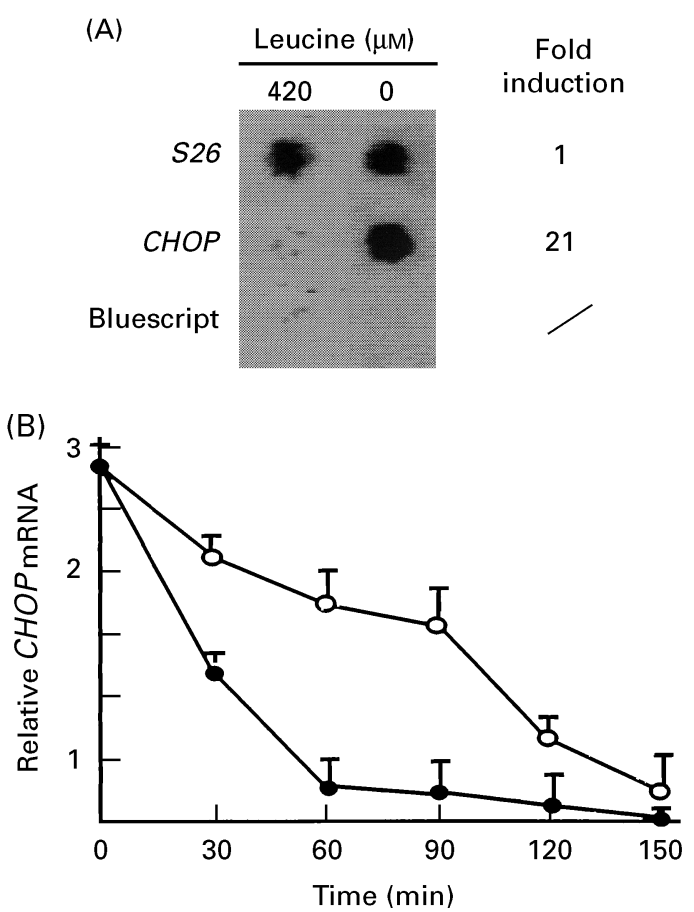

Fig. 3. Transcriptional and post-transcriptional regulation of CCAAT/ enhancer-binding protein homologous protein $(C H O P)$ by leucine deprivation. (A) Nuclear run-on analysis of $\mathrm{CHOP}$ transcription. HeLa cells were incubated for $4 \mathrm{~h}$ in DMEM/F12 control medium (Sigma, St Louis, MO, USA; $420 \mathrm{mM}$ ) or in DMEM/F12 medium lacking leucine $(0 \mathrm{~mm})$. ${ }^{32} \mathrm{P}$-labelled RNA isolated from HeLa cells was hybridized to filter-bound DNA of ribosomal S26, CHOP and bluescript vector. The fold induction was determined as the ratio, mRNA expressed in leucine-deprivation: non-deprived mediums. (B) Effect of leucine deprivation on CHOP mRNA stability. HeLa cells were initially incubated for $16 \mathrm{~h}$ in DMEM/F12 medium lacking leucine. At this point (time 0 ), cells were incubated, in the presence of $4 \mathrm{mg}$ actinomycin $\mathrm{D} / \mathrm{ml}$, either in DMEM/F12 medium (-) or in DMEM/F12 medium lacking leucine $\left(\mathrm{O}_{-} \mathrm{O}\right)$. Total RNA was extracted from each group of cells after the indicated incubation times and CHOP mRNA was analysed by Northern blotting.

levels. In deprived cells, the $C H O P$ mRNA half-life was increased about 3-fold compared with cells incubated in the control medium. These findings indicate that leucine deprivation elevates $C H O P$ mRNA levels both by increasing the rate of $C H O P$ transcription and by enhancing the stability of $C H O P$ mRNA.

\section{Regulation of $\mathrm{CHOP}$ promoter activity by leucine deprivation}

To analyse the role of $\mathrm{pCHOP}$ in transcription activation by leucine deprivation, a chimeric gene (pCHOP-luciferase; LUC) containing the $5^{\prime}$ flanking sequence from nucleotides -954 to +91 fused to the $L U C$ gene was transiently transfected in HeLa cells under leucine-deprived or normal conditions. The data presented in Fig. 4 show that LUC activity expressed under the control of $\mathrm{pCHOP}$ was induced 7-fold by $16 \mathrm{~h}$ of leucine deprivation. These results give direct evidence that regulation of $C H O P$ transcription by leucine 
(A)

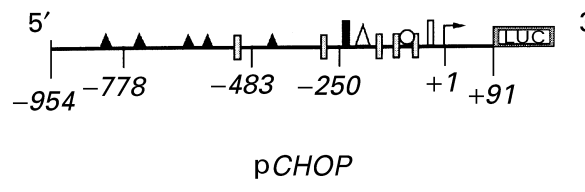

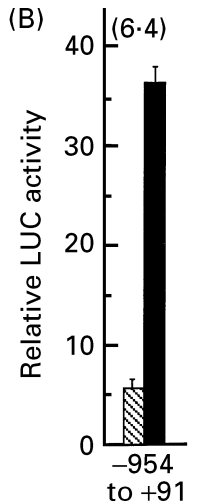

Fig. 4. Regulation of luciferase (LUC) activity under the control of the CHOP promoter in leucine-deprived cells. (A) The plasmid pCHOP-LUC corresponds to the human CHOP promoter (pCHOP) region from nucleotide -954 to +91 fused to the LUC gene. The putative binding site for the main transcription factors are represented: $(\mathbf{\Delta})$, interleukin 6 response element; $(\mathbf{I}), S p-1 ;(\triangle)$, C-ETS-1; (O), CCAAT box; (I), AP-1; ( $\square$ ) TATA box. (B) Hela cells were transiently transfected with plasmid pCHOP-LUC along with plasmid $p C M V-\beta G A L$ where $p C M V$ is cytomegalo virus promoter carrying the $\beta$-galactosidase $(E C$ 3.2.1.23; $\beta G A L)$ gene. At $24 \mathrm{~h}$ after transfection, cells were incubated for $16 \mathrm{~h}$ in DMEM/F12 medium (Sigma, St Louis, MO, USA; $420 \mu \mathrm{M}$; $\equiv$ ) or in DMEM/F12 medium lacking leucine ( $\mathbf{\square})$, then harvested for preparation of cells extracts, and LUC and $\beta G A L$ activities were determined. Transfection efficiency was calibrated using $\beta G A L$ activity. Results are given as LUC activity relative to $\beta G A L$ activity). Values are means and standard deviations represented by vertical bars.

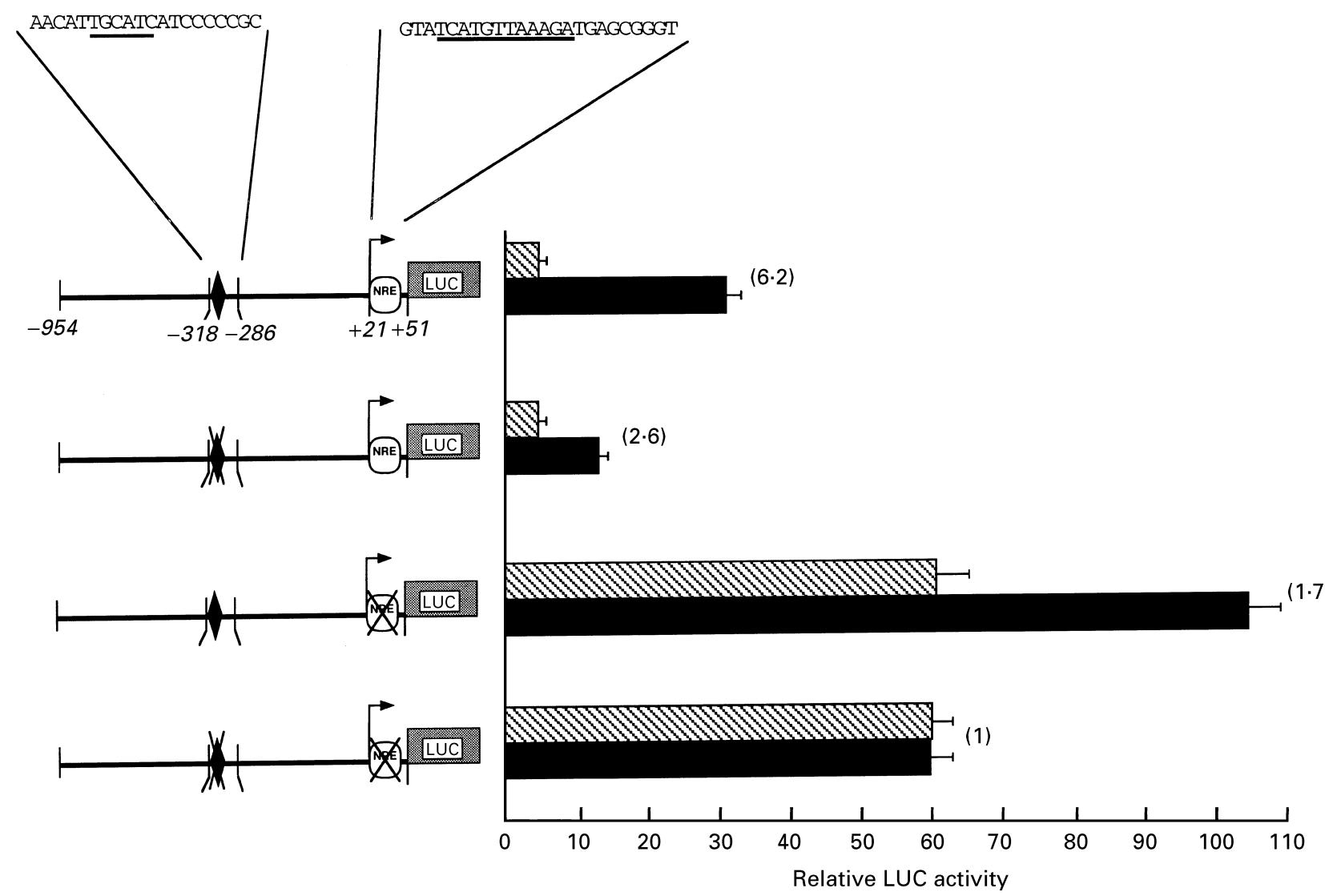

Fig. 5. Identification of the $C H O P$ promoter region involved in the regulation by leucine limitation. Mutations of the $C H O P$ promoter (pCHOP; in pCHOP-LUC, a chimeric gene containing the $5^{\prime}$ flanking sequence from nucleotides -954 to +91 fused to the luciferase (LUC) gene) were created by a polymerase chain reaction-based method. The mutated sequences are 'underlined'. The cells were transfected and then incubated for $16 \mathrm{~h}$ in a control medium (420 $\mu \mathrm{M}$-leucine; $\mathbb{\mathbb { M }})$ or in a medium lacking leucine $(\boldsymbol{\square})$, and then harvested for preparation of cell extracts, and LUC and $\beta$-galactosidase (EC 3.2.1.23) activities were determined. Tranfection efficiency was calibrated using $\beta$-galactosidase activity. Results are given as LUC activity relative to $\beta$-galactosidase activity. NRE, negative regulatory element. Values shown in parentheses are relative fold induction (LUC activity of leucine-deprived cells : LUC activity of control cells). Values are means and standard deviations represented by horizontal bars. 


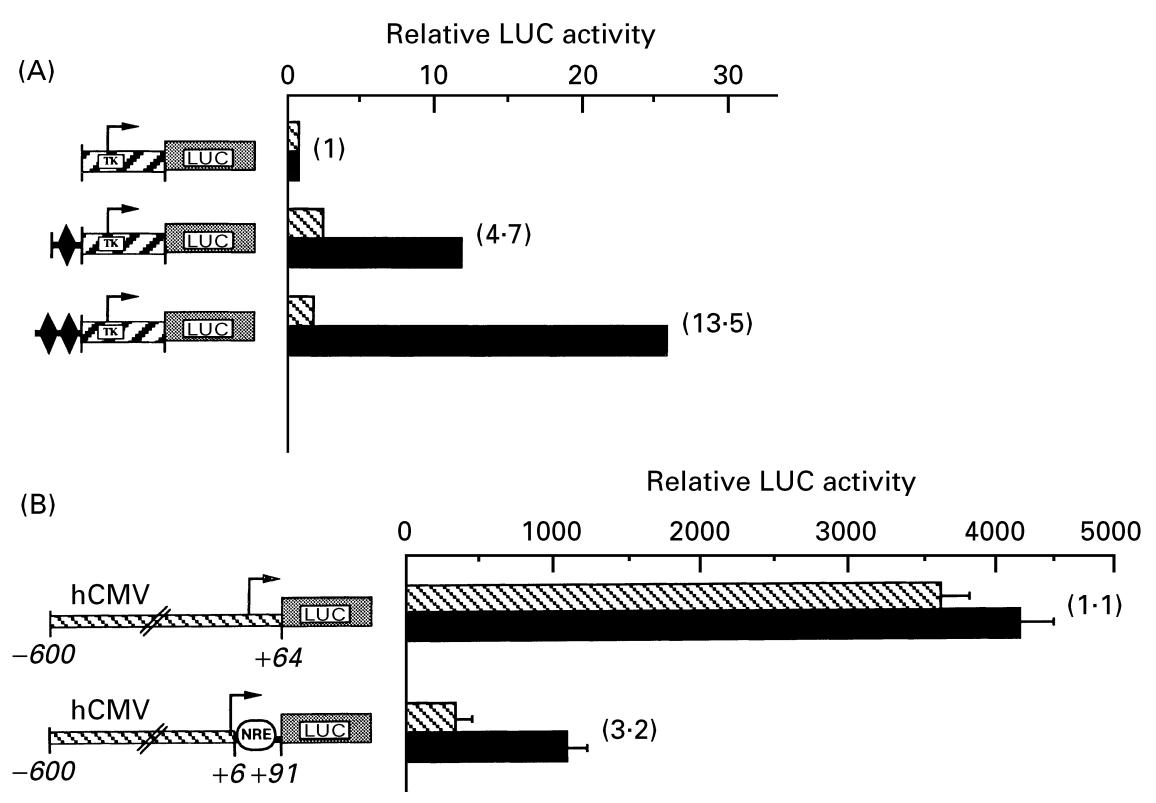

Fig. 6. Leucine deprivation activation of the amino acid-responsive elements placed in a heterologous promoter. (A) The $C H O P$ amino acidresponse element $(\$)$ was placed in one or two copies upstream $(-318,-286)$ of a minimum thymidine kinase $(E C 2.7 .1 .21 ;$ TK $)$ promoter driving the luciferase (LUC) construct. The cells were transfected and then incubated for $16 \mathrm{~h}$ in a control medium $(420 \mu \mathrm{M}$-leucine; $\mathrm{am})$ or in a medium lacking leucine $(\boldsymbol{\square})$ and then harvested for preparation of cell extracts, and LUC and $\beta$-galactosidase (EC 3.2.1.23) activities were determined. Transfection efficiency was calibrated using $\beta$-galactosidase activity. Results are given as LUC activity relative to $\beta$-galactosidase activity. (B) The $\mathrm{CHOP}$ negative regulatory element (NRE) was placed downstream of a strong promoter (human cytomegalo virus (hCMV) promoter) driving LUC construct and transfected into HeLa cells. The cells were then incubated for $16 \mathrm{~h}$ in a control medium $(420 \mu \mathrm{M}$-leucine; $\mathbb{\text { alv }}$ ) or in a medium lacking leucine $(\boldsymbol{\square})$ and LUC activity was assayed as described previously. Values shown in parentheses are relative fold induction (LUC activity of leucine-deprived cell : LUC activity of control cells. Values are means and standard deviations represented by horizontal bars.

deprivation is mediated through the promoter sequence situated between nucleotides -954 to +91 . Similarly, increased levels of LUC activity were also observed following transfection of pCHOP-CAT into other cell lines: HepG2 and Caco-2 cells (data not shown).

$\mathrm{pCHOP}$ contains numerous regulatory elements that are likely to function in controlling the expression of this gene in response to amino acid limitation. Serial deletions and mutations of $\mathrm{pCHOP}$ were undertaken to highlight regions responsive to amino acid deprivation (A Bruhat, C Jousse, $\mathrm{S}$ Blinet, M Ferrara and P Fafournoux, unpublished results). Two cis DNA elements which are important for amino acid regulation of $\mathrm{pCHOP}$ were identified. The first one is located in the region spanning nucleotides -313 to -295 and contains an amino acid response element. A mutation of this region markedly affects the amino acid regulation of $\mathrm{pCHOP}$ activity (Fig. 5). The second one is located downstream of the transcription initiation site of the CHOP gene. When this sequence is mutated the basal LUC activity is dramatically increased and the transcriptional activity of the promoter is still enhanced in response to leucine deprivation (Fig. 5). This element can be referred to as a negative regulatory element. When both regulatory elements are mutated $\mathrm{pCHOP}$ activity is no longer regulated by a leucine limitation (A Bruhat, $\mathrm{C}$ Jousse, S Blinet, M Ferrara and P Fafournoux, unpublished results).

In order to provide further evidence relating to the role of these two elements in the control of gene expression, we transferred the amino acid responsiveness to a heterologous promoter (Fig. 6). We inserted one or two copies of the amino acid response element of $\mathrm{pCHOP}$ into a minimum promoter sequence of the thymidine kinase ( $E C$ 2.7.1.21) gene. Fig. 6 shows that the $C H O P$ amino acid response element sequence is enough to confer an amino acid regulation to the thymidine kinase promoter. We also tested the amino acid responsiveness of the $C H O P$ negative regulatory element described previously. We inserted one copy of this sequence into the leader of the $L U C$ gene driven by a strong promoter (cytomegalo virus) which is an early enhancer promoter region. As shown in Fig. 6, the negative regulatory element sequence dramatically decreases the LUC activity and confers an amino acid responsiveness to the cytomegalo virus promoter.

We have identified and characterized two elements of the CHOP gene essential to the transcriptional activation produced by an amino acid limitation. Further work will be required to identify precisely the trans-acting factor(s) involved in the regulation of the $C H O P$ promoter as well as the mechanism of its activation by amino acid deprivation.

Our results represent the first demonstration that a shortage of amino acids, such as that occurring in proteinrestricted animals, can control gene expression. Thus, amino acids by themselves can play, in concert with hormones, an important role in the control of gene expression. These studies will allow an understanding of the role of amino acids in the regulation of physiological functions (growth, proteolysis etc.). Defining the molecular steps by 
which the cellular concentration of individual amino acids can regulate gene expression will be an important contribution to our understanding of metabolite control in mammalian cells.

\section{References}

Baertl JM, Placko RP \& Graham GG (1974) Serum proteins and plasma free amino acids in severe malnutrition. American Journal of Clinical Nutrition 27, 733-742.

Baker J, Liu JP, Robertson EJ \& Efstratiadis A (1993) Role of insulin-like growth factors in embryonic and postnatal growth. Cell 75, 73-82.

Barlett JD, Luethy JD, Carlson SG, Sollott SJ \& Holbrook NJ (1992) Calcium ionophore A23187 induces expression of the growth arrest and DNA damage inducible CCAAT/enhancerbinding protein (C/EBP)-related gene, gadd153. Journal of Biological Chemistry 267, 20465-20470.

Binoux M (1995) The IGF system in metabolism regulation. Diabetes and Metabolism 21, 330-337.

Brismar K, Gutniak M, Povoa G, Werner S \& Hall K (1988) Insulin regulates the $35 \mathrm{kDa}$ IGF binding protein in patients with diabetes mellitus. Journal of Endocrinological Investigation 11, 599-602.

Bruhat A, Jousse C, Wang XZ, Ron D, Ferrara M \& Fafournoux P (1997) Amino acid limitation induces expression of CHOP, a CCAAT/enhancer binding protein-related gene, at both transcriptional and post-transcriptional levels. Journal of Biological Chemistry 272, 17588-17593.

Busby WH, Snyder DK \& Clemmons DR (1988) Radioimmunoassay of 26,000-dalton plasma insulin-like growth factor-binding protein: control by nutritional variables. Journal of Clinical Endocrinology and Metabolism 67, 1122511230.

Carlson SG, Fawcett TW, Barlett JD, Bernier M \& Holbrook NJ (1993) Regulation of the C/EBP-related gene gadd153 by glucose deprivation. Molecular and Cellular Biology 13, 47364744.

Cotterill AM, Cowell CT, Baxter RC, McNeil D \& Silinik M (1988) Regulation of the growth hormone-independent growth factorbinding protein in children. Journal of Clinical Endocrinology and Metabolism 67, 882-887.

Coward WA \& Lunn PG (1981) The biochemistry and physiology of kwashiorkor and marasmus. British Medical Bulletin 37, 1924

Donovan SM, Atilano LC, Hintz RL, Wilson DM \& Rosenfeld RG (1991) Differential regulation of the insulin-like growth factors (IGF-I and -II) and IGF binding proteins during malnutrition in the neonatal rat. Endocrinology 129, 149-157.

Fafournoux P, Rémésy C \& Demigné C (1990) Fluxes and membrane transport of amino acids in rat liver under different protein diets. American Journal of Physiology 259, E614-E625.

Fornace AJ, Alamo J Jr \& Hollander MC (1988) DNA damageinducible transcripts in mammalian cells. Proceedings of the National Academy of Sciences USA 85, 8800-8804.

Gay E, Seurin D, Babajko S, Doublier S, Cazillis M \& Binoux M (1997) Liver-specific expression of human insulin-like growth factor binding protein-1 in transgenic mice: Repercussions on reproduction, ante- and perinatal mortality and postnatal growth. Endocrinology 138, 2937-2947.

Girard J, Perdereau D, Foufelle F, Prip-Buus C \& Ferré P (1994) Regulation of lipogenic enzyme gene expression by nutrients and hormones. FASEB Journal 8, 36-42.

Grimble RF \& Whitehead RG (1970) Fasting serum-amino acid patterns in kwashiorkor and after administration of different levels of protein. Lancet i, 918-920.
Gurney AL, Pak EA, Liu J, Giralt M, McGrane MM, Patel YM, Crawford DR, Nizielski SE, Savon S \& Hanson RW (1994) Metabolic regulation of gene transcription. Journal of Nutrition 124, 1533S-1539S.

Jackson AA \& Grimble RF (1990) Malnutrition and amino acid metabolism. In The Malnourished Child. Nestle Nutrition Workshop Series, vol. 19, pp. 73-94 [RM Suskind and LL Suskind, editors]. New York: Vevey Raven Press.

Jousse C, Bruhat A, Ferrara M \& Fafournoux P (1998) Physiological concentration of amino acids regulates insulinlike-growth-factor-binding protein 1 expression. Biochemical Journal 334, 147-153.

Kilberg MS, Hutson RG \& Laine RO (1994) Amino acid-regulated gene expression in eukaryotic cells. FASEB Journal 8, 13-19.

Kita K, Tomas FM, Owens PC, Knowles SE, Forbes BE, Upton Z, Hughes R \& Ballard FJ (1996) Influence of nutrition on hepatic IGF-I mRNA levels and plasma concentrations of IGF-I and IGF-II in meat-type chickens. Journal of Endocrinology 149, 181-190.

Lee PDK, Conover CA \& Powell DR (1993) Regulation and function of insulin-like growth factor-binding protein-1. Proceedings of the Society for Experimental Biology and Medicine 204, 4-29.

Lewitt MS, Denyer GS, Cooney GJ \& Baxter RC (1991) Insulinlike growth factor-binding protein-1 modulates blood glucose levels. Endocrinology 129, 2254-2256.

Luethy JD \& Holbrook NJ (1992) The pathway regulating GADD153 induction in response to DNA damage is independent of protein kinase $\mathrm{C}$ and tyrosine kinases. Cancer Research 54, 1902S-1906S.

Palacin M, Estévez R, Bertran J \& Zorzano A (1998) Molecular biology of mammalian plasma membrane amino acid transporters. Physiological Review 78, 969-1045.

Rajkumar K, Barron D, Lewitt MS \& Murphy LJ (1995) Growth retardation and hyperglycemia in insulin-like growth factor binding protein-1 transgenic mice. Endocrinology 136, 40294034.

Rajkumar K, Krsek M, Dheen ST \& Murphy LJ (1996) Impaired glucose homeostasis in insulin-like growth factor binding protein-1 transgenic mice. Journal of Clinical Investigation $\mathbf{9 8}$, $1818-1825$.

Straus DS (1994) Nutritional regulation of hormones and growth factors that control mammalian growth. FASEB Journal 8, 6-12.

Straus DS, Burke EJ \& Marten NW (1993) Induction of insulin-like growth factor binding protein-1 gene expression in liver of protein-restricted rats and in rat hepatoma cells limited for a single amino acid. Endocrinology 132, 1090-1100.

Straus DS \& Takemoto CD (1990) Effect of dietary protein deprivation on insulin-like growth factor-I and -II, IGF binding protein-2, and serum albumin gene expression in rat. Endocrinology 127, 1849-1860.

Suikkari AM, Koivisto VA, Rutanen EM, Yki-Järvinen H, Karonen SL \& Seppälä M (1988) Insulin regulates the serum levels of low molecular weight insulin-like growth factor-binding protein. Journal of Clinical Endocrinology and Metabolism 66, 266-272.

Sylvester SL, ap Rhys CMJ, Luethy-Martindale JD \& Holbrook NJ (1994) Induction of GADD153, a CCAAT-enhancer-binding protein $(\mathrm{C} / \mathrm{EBP})$-related gene, during the acute phase response in rats. Journal of Biological Chemistry 269, 20119-20125.

Towle HC (1995) Metabolic regulation of gene transcription in mammals. Journal of Biological Chemistry 270, 23235-23238.

Vance ML, Hartman ML \& Thorner MO (1992) Growth hormone and nutrition. Hormone Research 38, 85-88.

Vaulont S \& Kahn A (1994) Transcriptional control of metabolic regulation genes by carbohydrates. FASEB Journal 8, 28-35.

Walton PE, Dunshea FR \& Ballard FJ (1995) In vivo actions of IGF analogues with poor affinities for IGFBPs: metabolic 
and growth effects in pigs of different ages and GH responsiveness. Proceedings of Growth Factor Research 6, 385-395.

Wang X-Z, Lawson B, Brewer JW, Zinszner H, Sanjay A, Mi L-J, Boorstein R, Kreibich G, Hendershot LM \& Ron D (1996) Signals from the stressed endoplasmic reticulum induce C/EBP- homologous protein (CHOP). Molecular and Cellular Biology 16, 4273-4280.

Wang ZZ, Kuroda M, Sok J, Batchvarova N, Kimmel R, Chung P, Zinszner H \& Ron D (1988) Identification of novel stressinduced genes downstream of chop. EMBO Journal 17, 36193630.

(C) Nutrition Society 1999 